UDC 005.8

A. BONDAR

\title{
MANAGEMENT OF HUMAN RESOURCES OF THE PROJECT-ORIENTED ORGANIZATION BASED ON THE PROFILE OF THE SPECIALIST AND THE DEGREE OF ITS UNIQUENESS
}

The subject of the research is the tools and methods of effective human management. The purpose of this study is the development of human management tools for a project-oriented organization. The following tasks had been solved in the article: introducing the categories of "specialist profile" and "degree of uniqueness" of an employee; identification of the main areas of use of the "specialist profile" and the indicator of "degree of uniqueness" in the human resources management of a project-oriented organization; development of the method for assessing the "degree of uniqueness" of an employee. The following methods are used: set theory, functional analysis, expert assessment method. Results. In this study the category "specialist profile" and the interrelated indicator "degree of employee uniqueness" were introduced. A specialist's profile means a combination of three components, which are the sets of quantitatively evaluated characteristics: competence, energy and professional potential were presented. The profile of the organization's specialist is examined for compliance not only with the essence of the project and its specific work, but also with the conditions of the project and work, as well as with the interests of the project-oriented organization. "Energy" is a set of personal characteristics of an employee, such as the ability to work in extreme situations, stress tolerance, sociability, etc. "Professional potential" - "hidden" professional opportunities (competencies, energy), which are transformed into real competencies and energy in the process of carrying out professional activities. A conceptual model for the use of the "employee profile" in the human resources management of a project-oriented organization had been developed. Under the degree of uniqueness of an employee is taken the ratio of his competencies, energy and potential to the competencies, energy and potential of other employees. Conclusions. The method for assessing the degree of uniqueness of an employee, illustrated by a calculation example, was developed. The directions of using this indicator in the human resources management of a project-oriented organization were indicated.

Keywords: human resources; competency; energy; potential; control; project; degree of uniqueness.

\section{Introduction}

The basis of project team management is a competency-based approach that allows you to compare the competencies of project team members and the capabilities of applicants to participate in the project and their subsequent assignment to specific project work. Nevertheless, not only competencies are the "driving force" of the project, other characteristics of individual specialists that either contribute to or hinder the successful implementation of the project are of great importance. In addition, for organizations (companies, enterprises) that follow the project approach in the implementation of their activities and their development, that is, they are projectoriented, project teams are formed from the totality of labor resources. Thus, unlike the separately considered project, employees of the organization can, for example, be considered as "alternative options" for participation in various projects of the organization. The specificity of the project-oriented organization necessitates the use of appropriate tools to effectively manage its workforce.

\section{Analysis of recent publications and studies}

Consideration of the problem of human resources management of project-oriented organizations is a logical dissemination and development of the results of research of project team management at a higher level - the level of the organization as a whole. Thus, this study should be carried out in the context of the synthesis of human resources management (classic HRM) and project team management. Such a vision has emerged in modern science over the past 15 years. In particular, in [1-3], the authors focus on the fact that the development and dissemination of project-oriented management ideas for companies and enterprises of various fields of activity gives rise to the recurrent problem of labor management of such organizations. And although the authors do not provide a specific methodology for solving this problem, they indicate its importance for modern theory and practice.

In [4], emphasis is placed on the need for career growth of employees, moreover, from the point of view of the well-being of a project-oriented organization. Despite the fact that the term "professional potential" is not used in this work, nevertheless, in this context we are talking about the career growth of the organization's specialists.

The work [5] summarizes various approaches to the management of labor resources, considering their development in a historical context, and focuses on the usefulness of the penetration of classical approaches to the management of labor resources in project management and in the management of project-oriented organizations. One of the conclusions here is the need for modern researchers to focus on human resources management in projects of project-oriented organizations.

In [6], the results of a statistical analysis of success factors in the context of human resources management of typical representatives of project-oriented organizations - software development companies - are presented. In particular, the following basic mechanisms for successful workforce management were established: assessment of the effectiveness of work, training and development, participation in decision making.

Among the works of the domestic school, it should be noted [7-11], which are devoted to the competencybased approach in project management. Note that, despite the significant attention of domestic researchers to projectoriented organizations (for example, [12]), problems 
related to labor resources at this level are practically not considered, as an exception, the works $[13,14]$, in which, however, the focus is mainly on projects, and not on the whole organization.

Based on the foregoing, the purpose of this study is the development of human resources management tools for a project-oriented organization.

\section{Research Objectives:}

- introduction of the categories of "specialist profile" and "degree of uniqueness" of an employee;

- identification of the main areas of use of the "specialist profile" and the indicator of "degree of uniqueness" in the labor management of a project-oriented organization;

- development of a method for assessing the "degree of uniqueness" of an employee.

Specialist profile and its use in the human resources management of a project-oriented organization.

The main requirement for the project team is that it has the qualities that ensure the success of the project. Moreover, these qualities are determined not only by the composition of competencies, but also by "energy" and professional potential. Such a conclusion was made in [15]. It should be noted that a clear identification of the components of energy and potential requires a separate study that is beyond the scope of this work; therefore, we restrict ourselves to introducing into consideration these characteristics of a unit of labor resources in the form of a set of corresponding estimates.

Moreover, we accept the following content of these concepts. "Energy" is a set of personal characteristics of an employee, such as the ability to work in extreme situations, stress tolerance, sociability, etc. We define professional potential as "hidden" professional opportunities (competencies, energy) that transform into real competencies and energy in the process of carrying out professional activities. It should be noted that the latter is possible only under certain conditions that are formed in the organization.

Without substantial concretization, we will accept the following structure of the characteristics of a unit of labor resources, which we define as a "specialist profile":

$$
\left\{C_{1}, C_{2}, \ldots, C_{n}, E_{1}, E_{2}, \ldots, E_{m}, P_{1}, P_{2}, \ldots, P_{s}\right\}
$$

$C_{1} C_{2}, \ldots, C_{n}-$ set $i=\overline{1, n}$ of competency ratings competency index;

$$
E_{1}, E_{2}, \ldots, E_{m}-\text { set of estimates of energy }
$$

components, $\quad j=\overline{1, m}$ - energy component index;

$$
P_{1}, P_{2}, \ldots, P_{s}-\text { set of potential assessments, } s=\overline{1, S}-
$$

potential component index.

If it is assumed that the components (1) are dimensionless quantities, for example, points or fractions of the "ideal" assessment, then the usual Euclidean distance taking into account the weight of the components can serve as a measure of "proximity of specialists":

$$
D_{12}=\sum_{i=1}^{n} \alpha_{i} \cdot\left(C_{i}^{1}-C_{i}^{2}\right)^{2}+\sum_{j=1}^{m} \beta_{j} \cdot\left(E_{j}^{1}-E_{j}^{2}\right)^{2}+\sum_{s=1}^{S} \gamma_{s} \cdot\left(P_{s}^{1}-P_{s}^{2}\right)^{2},
$$

where $\alpha_{i}, \beta_{j}, \gamma_{s}, i=\overline{1, n}, j=\overline{1, m}, s=\overline{1, S}$ - the weight of the specialist profile components for which:

$$
\sum_{i=1}^{n} \alpha_{i}+\sum_{j=1}^{m} \beta_{j}+\sum_{s=1}^{S} \gamma_{s}=1
$$

$C_{i}^{1}, E_{j}^{1}, P_{s}^{1}, C_{i}^{2}, E_{j}^{2}, P_{s}^{2}$ - accordingly, the profile components of the 1 st and 2 nd specialist. In accordance with minimization (2), in particular, specialists can be replaced if necessary within the organization.

Such an approach to identifying the "specificity" of specialists (employees) can be widely used in deciding on the formation of a project team and assigning specialists to work. So, depending on the specifics of individual project activities, special requirements for profile components may be put forward.

For example, a specific job requires several specialists with specific competencies $C_{1}, C_{2}, \ldots, C_{n^{\prime}}$. The $L$ most probable conditions for the implementation of the project are forecasted; accordingly, it is required to select several employees whose competencies correspond to this work, and "energy" corresponds to one of the most probable environmental conditions $E_{11}, E_{21}, \ldots ., E_{m^{\prime} 1}, . ., E_{1 L}, E_{2 L}, \ldots ., E_{m^{\prime} L}$. The organization also has certain strategic goals and projected projects, which determines the need to "disclose" a certain potential of employees $P_{1}, P_{2}, \ldots, P_{S^{\prime}}$. Thus, the profile of the organization's specialist is examined for compliance not only with the essence of the project and its specific work, but also with the conditions of the project and work, as well as with the interests of the project-oriented organization (fig. 1).

This approach will ensure not only the success of a specific project, but also the success of promising projects (in the future) of the organization by uncovering the potential of its employees.

Since in a project-oriented organization, as a rule, several projects are implemented at the same time, and project teams are formed from the aggregate workforce of the organization, a situation often arises of a choice: which of the employees with close "competency content" to include in a particular project team. In such cases, the proposed approach to the formation of an employee profile can serve as the basis for this choice.

Note that the proposed "profiling" of employees will also allow adequate selection of personnel. Special methods of testing can be used to identify specific components of "energy" and "potential".

The degree of uniqueness of the employee and the method of its assessment.

By the degree of uniqueness of an employee of a project-oriented organization, we mean the ratio of his competencies, energy and potential with the competencies, energy and potential of other employees. According to this definition, the smaller the organization's staff, the higher the degree of uniqueness of each of the employees (labor units) and, accordingly, vice versa. 


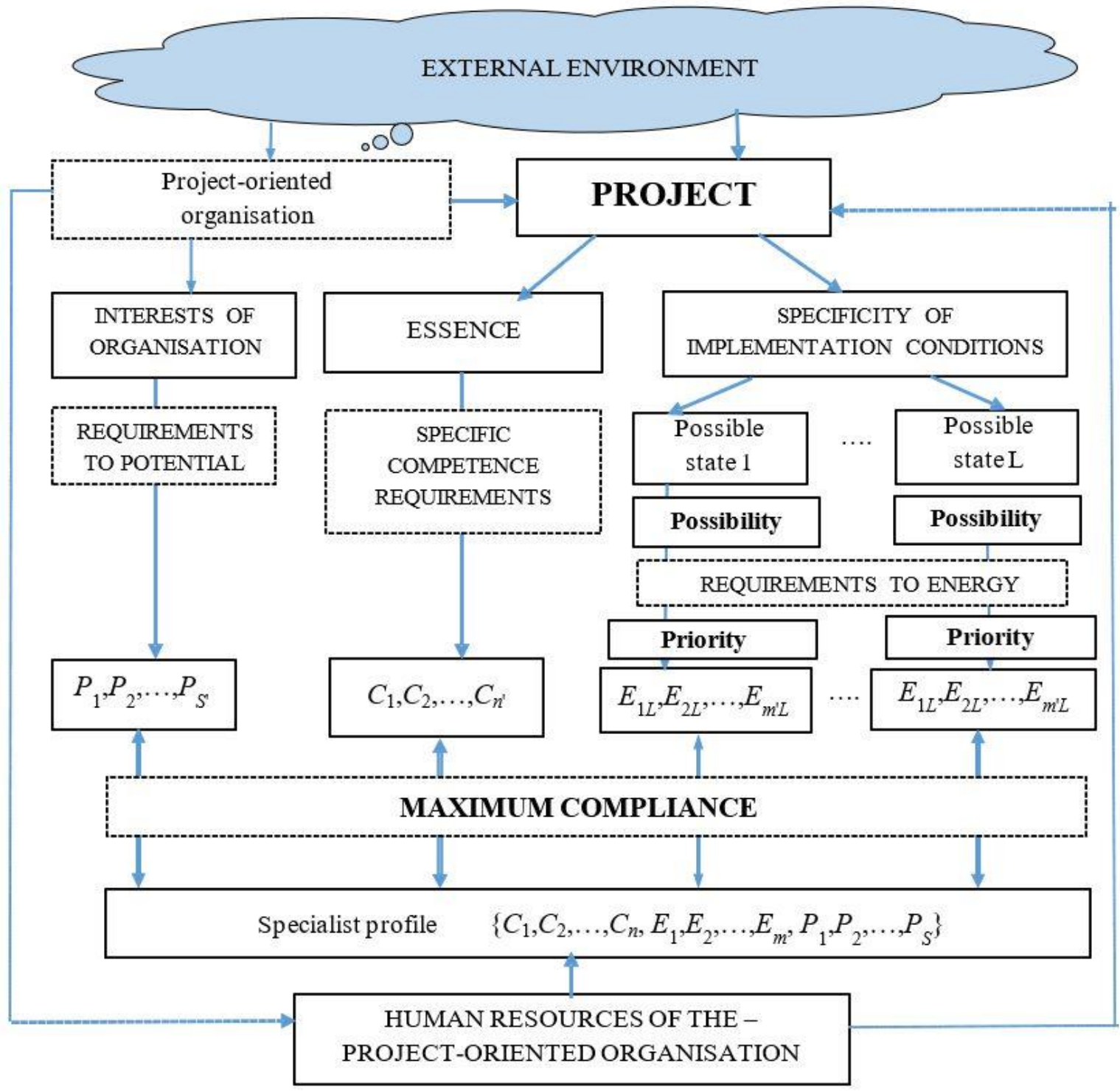

Fig. 1. The use of "specialist profile" in decision-making processes on the formation of a project team in a project-oriented organization

To ensure the success of the project, specialists with a high degree of uniqueness must be present in the project team, which will allow them to a) make non-standard decisions as compared to other team members, b) realize the existing potential to the maximum extent (which will be valuable for the project-oriented organization in future), c) use "energy opportunities" in turbulence.

To assess the uniqueness of a unit of labor at the level of a project-oriented organization, the following method is proposed.

Let the labor resources of a project-oriented organization be $\mathrm{H}+1$ people. Excluding the employee for whom the degree of uniqueness is evaluated, $\mathrm{N}$ people remain. Then, for each employee from among the organization's labor resources, a set of characteristics is given:

$$
\left\{C_{1}^{h}, C_{2}^{h}, \ldots, C_{n}^{h}, E_{1}^{h}, E_{2}^{h}, \ldots ., E_{m}^{h}, P_{1}^{h}, P_{2}^{h}, \ldots, P_{s}^{h}\right\}, h=\overline{1 . H}
$$

$C_{1}^{h}, C_{2}^{h}, \ldots, C_{n}^{h}-$ set of competency assessments, $i=\overline{1, n}-$ competency index;

$$
E_{1}^{h}, E_{2}^{h}, \ldots ., E_{m}^{h}-\text { set of estimates of energy }
$$

components, $j=\overline{1, m}$ - energy component index;

$$
P_{1}^{h}, P_{2}^{h}, \ldots, P_{s}^{h}-\text { set of potential assessments, }
$$
$s=\overline{1, S}-$ potential component index.

The following indicator is proposed to assess the degree of employee uniqueness:

$$
U_{P}=\sum_{i=1}^{n} \alpha_{i} \frac{N_{i}}{Q_{H R}}+\sum_{j=1}^{m} \beta_{j} \frac{M_{j}}{Q_{H R}}+\sum_{s=1}^{S} \gamma_{s} \frac{Z_{s}}{Q_{H R}}
$$

or

$$
U_{P}=\frac{1}{Q_{H R}}\left(\sum_{i=1}^{n} \alpha_{i} \cdot N_{i}+\sum_{j=1}^{m} \beta_{j} \cdot M_{j}+\sum_{s=1}^{S} \gamma_{s} \cdot Z_{s}\right),
$$

where: 


$$
\begin{gathered}
N_{i}=\sum_{h=1}^{H} I_{i}^{h}, i=\overline{1, n}, \\
I_{i}^{h}=\left\{\begin{array}{l}
1, C_{i}^{h} \geq C_{i} ; \\
0, C_{i}^{h}<C_{i} .
\end{array}, i=\overline{1, n}, h=\overline{1, H},\right. \\
M_{j}=\sum_{h=1}^{H} I_{j}^{h}, j=\overline{1, m}, \\
I_{j}^{h}=\left\{\begin{array}{l}
1, E_{j}^{h} \geq E_{j} ; \\
0, E_{j}^{h}<E_{j} .
\end{array}, j=\overline{1, m}, h=\overline{1, H},\right. \\
Z_{s}=\sum_{h=1}^{H} I_{s}^{h}, s=\overline{1, S}, \\
I_{s}^{h}=\left\{\begin{array}{l}
1, P_{s}^{h} \geq P_{s} ; \\
0, P_{s}^{h}<P_{s} .
\end{array}, \overline{1, S}, h=\overline{1, H},\right.
\end{gathered}
$$

In fact, (7), (9) and (11) establish the number of people for whom the characteristic in question (competence, component of energy or potential) is the same or higher than that of the employee in question. The presence in the denominators (5) and (6) $Q_{H R}$ allows, in fact, to determine the share of employees with a given characteristic and even the best in the total workforce. The calculation example was based on the following initial data (table 1).

The table 2 shows the intermediate and final results of calculating the indicator of the degree of uniqueness of a unit of labor resources. In this example, the value of this indicator was 0.45 . Note that based on the data in table 2 , an employee profile can be formed in the form of a graphical representation (fig. 2).

$Q_{H R}$ - the amount of labor resources of the organization.

Table 1. The source data for the calculation of the degree of uniqueness of a unit of labor

\begin{tabular}{|c|c|c|c|c|c|}
\hline \multirow{2}{*}{ Characteristics } & \multirow{2}{*}{ Indicator for an employee } & \multicolumn{4}{|c|}{ Indicator for colleagues } \\
\cline { 3 - 6 } & 10 & $\boldsymbol{h = 1}$ & $\boldsymbol{h = 2}$ & $\boldsymbol{h}=\mathbf{3}$ & $\boldsymbol{h}=\mathbf{4}$ \\
\hline$C_{1}, C_{1}^{h}$ & 9 & 8 & 10 & 9 & 3 \\
\hline$C_{2}, C_{2}^{h}$ & 9 & 6 & 7 & 8 & 3 \\
\hline$C_{3}, C_{3}^{h}$ & 7 & 5 & 5 & 9 & 7 \\
\hline$C_{4}, C_{4}^{h}$ & 3 & 4 & 4 & 6 & 8 \\
\hline$C_{5}, C_{5}^{h}$ & 4 & 9 & 8 & 10 & 2 \\
\hline$C_{6}, C_{6}^{h}$ & 5 & 5 & 6 & 8 & 10 \\
\hline$E_{1}, E_{1}^{h}$ & 8 & 10 & 7 & 7 & 4 \\
\hline$E_{2}, E_{2}^{h}$ & 7 & 7 & 7 & 5 & 7 \\
\hline$P_{1}, P_{1}^{h}$ & 5 & 6 & 5 & 5 & 8 \\
\hline$P_{2}, P_{2}^{h}$ & 10 & 7 & 3 & 9 \\
\hline
\end{tabular}

\begin{tabular}{|c|c|c|c|}
\hline$\alpha_{i}, \beta_{j}, \gamma_{s}$ & $N_{i}, M_{j}, Z_{s}$ & $\frac{N_{i}}{Q_{H R}}, \frac{M_{i}}{Q_{H R}}, \frac{Z_{s}}{Q_{H R}}$ & $\alpha_{i} \frac{N_{i}}{Q_{H R}}, \beta_{j} \frac{M_{i}}{Q_{H R}}, \gamma_{s} \frac{Z_{s}}{Q_{H R}}$ \\
\hline 0,1 & 1 & 0,25 & 0,025 \\
\hline 0,1 & 0 & 0 & 0 \\
\hline 0,2 & 1 & 0,25 & 0,05 \\
\hline 0,05 & 1 & 0,25 & 0,0125 \\
\hline 0,05 & 3 & 0,75 & 0,0375 \\
\hline 0,05 & 4 & 1 & 0,05 \\
\hline 0,3 & 3 & 0,75 & 0,225 \\
\hline 0,05 & 0 & 0 & 0 \\
\hline 0,05 & 1 & 0,25 & 0,0125 \\
\hline 0,05 & 3 & 0,75 & 0,0375 \\
\hline \multicolumn{3}{|c|}{$U_{P}$} & 0,45 \\
\hline
\end{tabular}

This profile allows you to visually see the "unique" characteristics. In addition, the presentation of data on

several employees on one diagram allows their comparative analysis (fig. 3).

Table 2. Calculation of the indicator of the degree of uniqueness of a unit of labor resources 


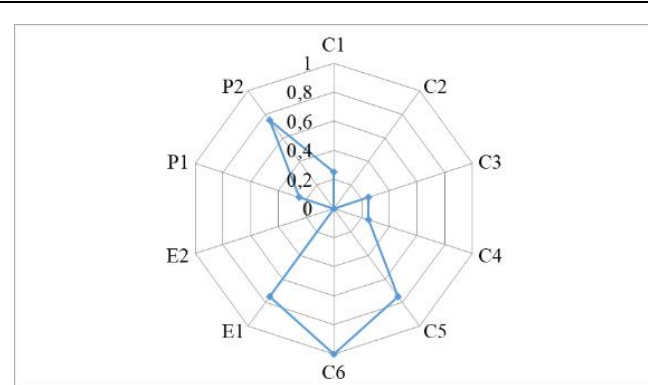

Fig. 2. The profile of the unit of labor resources

The closer to 0 the values of the individual components in (5), (6) and, accordingly, in the diagram in fig. 2, the more "unique" this characteristic is for the employee in question. So, in this example, competencies $1,2,3$, component of energy 1 and potential 1 form the basis of the "uniqueness" of this employee.

Using weights in (5), (6), respectively, the significance of individual characteristics in the indicators of the degree of uniqueness increases or decreases.

Fig. 3 shows the profiles of two employees who are practically opposites and have different characteristics with a high degree of uniqueness (HR2 - the employee discussed above, the calculation of the degree of uniqueness is presented in table 2 , for HR1, the degree of uniqueness was 0.52 .

Thus, we conclude that HR2 has a higher degree of uniqueness than HR1. According to the profile in fig. 3 it is clearly seen that HR2 number of characteristics closer to 0 is greater than that of HR1.

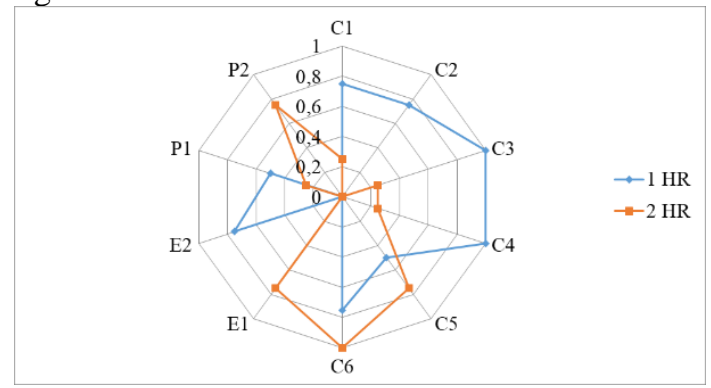

Fig. 3. Comparison of labor unit profiles
Thus, a method for assessing the degree of uniqueness for a unit of labor resources in the framework of a project-oriented organization is proposed and illustrated by a calculation example.

Obviously, such an assessment should be carried out differentially for different categories of labor resources, taking into account the specifics of competencies and components of energy and potential.

The degree of uniqueness can serve as a tool in resolving issues, for example, about hiring or generating a wage offer. Naturally, the higher the uniqueness of the employee, the higher the salary should be (with the proviso that the uniqueness of the employee must correspond to those characteristics that are most valuable and necessary for the organization).

\section{Conclusions}

In this study, the category "specialist profile" and the interrelated indicator "degree of employee uniqueness" are introduced.

A specialist's profile is understood to mean a combination of three components, which are sets of quantitatively evaluated characteristics: competence, energy, and professional potential. A conceptual model for the use of the "employee profile" in the human resources management of a project-oriented organization has been developed.

Under the degree of uniqueness of an employee, the ratio of his competencies, energy and potential to the competencies, energy and potential of other employees is taken. A method for assessing the degree of uniqueness of an employee is developed, which is illustrated by a calculation example. The directions of using this indicator in the human resources management of a project-oriented organization are indicated.

A further direction of this study is the development of formalized methods and models for solving specific tasks of labor management using the approach presented in this paper.

\section{References}

1. Söderlund, J., Bredin K. (2006), "HRM in Project-Intensive Firms: Changes and Challenges", Human Resource Management, No. 45 , P. 249-265.

2. Amy C. Edmondson, Jean-François Harvey (2018), "Cross-boundary teaming for innovation: Integrating research on teams and knowledge in organizations", Human Resource Management Review, Vol, 28, Issue 4, P. 347-360. DOI: https://doi.org/10.1016/j.hrmr.2017.03.002

3. Jamie, A. Gruman, Alan, M.Saks, (2011), "Performance management and employee engagement", Human Resource Management Review, Vol. 21, Issue 2, P. 123-136. DOI: https://doi.org/10.1016/j.hrmr.2010.09.004

4. Turner, R., Huemann, M., Keegan, A. (2008), "Human resource management in the project-oriented organization: Employee wellbeing and ethical treatment", International Journal of Project Management, Vol. 26, Issue 5, P. 577-585. DOI: https://doi.org/10.1016/j.ijproman.2008.05.005

5. Keegan, A., Ringhofer, C., Huemann, M. (2018) "Human resource management and project based organizing: Fertile ground, missed opportunities and prospects for closer connections", International Journal of Project Management, Vol. 36, Issue 1, P. 121-133. DOI: https://doi.org/10.18485/epmj.2019.9.1.5

6. Wickramasinghe, V., Liyanage, S., (2013), "Effects of high performance work practices on job performance in project-based organizations", Project Management Journal, No. 44 (3), P. 64-77. DOI: https://doi.org/10.1002/pmj.21342.

7. Bushuyev, S. D., Yaroshenko, F., Yaroshenko, N. (2013), "Entrepreneurial energy in the management of development projects" ["Predprinimatel'skaya energiya v upravlenii proyektami razvitiya"], Project management and production development, No. 2, P. 5-12.

8. Bushuyev, S. D. Bushuyeva, N. S. (2006), Competent Look at: Project Management. Basics of Professional Knowledge and Competence Assessment System for Project Managers (NCB UA v.3.0. [Kompetentnyy vzglyad na: upravleniye proyektami". 
Osnovy professional'nykh znaniy i sistema otsenki kompetentnosti proyektnykh menedzherov (NCB UA v.3.0)], Kyiv :ÍRÍDÍUM, $208 \mathrm{p}$.

9. Rach, V. A., Biryukov, O. V. (2008), "Context-personal assessment of the competence of project managers" ["Kontekstnolichnostnoye otsenivaniye kompetentnosti proyektnykh menedzherov"], Project management and production development, No. 3 (27), P. 67-81.

10. Biryukov, O. V. (2011), "Assessing the competence of a project management team with regard to the synergy effect" ["Otsenka kompetentnosti komandy upravleniya proyektom s uchetom effekta sinergii"], Project management and production development, No. 1 (37), P. 26-37.

11. Rossoshans'ka, O. V., Bíryukov, O. V. (2010), "Formation of project management team based on competence approach" ["Formuvannya komandi upravlínnya realízatsíeyu proyektu na osnoví kompetentnísnogo pídkhodu"], Project management and production development, No. 1 (33), P. 127-146.

12. Kadykova, I. N., Larina, S. A., Chumachenko, I. V. (2017), "Information technology for strategic management of a projectoriented organization" ["Ynformatsyonnaya tekhnolohyya stratehycheskoho upravlenyya proektno-oryentyrovannoy orhanyzatsyey"], News of NTU "KhPI". Seriya: Strategic management, portfolio management, programs and projects, No. 3 (1225), P. 9-15. DOI: https://doi.org/10.20998/2413-3000.2017.1225.2

13. Sulim-Timovti, A. A., Trifonov, I. V., Kornienko, E. O. (2010), "Determination of expected labor costs in a project-oriented organization" ["Vyznachennya ochikuvanykh trudovytrat za proektom u proektno-oriyentovanykh orhanizatsiyakh"], Construction, materials science, mechanical engineering, PSASA, No. 54, P. 174-180.

14. Zachko, O., Kobylkin, D., Kovalchuk, O. (2019), "Models of project teams' formation in a safety-oriented system", Innovative Technologies and Scientific Solutions for Industries, No. 4 (10), P. 85-91. DOI: https://doi.org/10.30837/2522-9818.2019.10.085

15. Bondar, A. V. (2019), "The concept of the human resources value of a project-oriented organization" ["Kontseptsiya tsinnosti lyuds'kykh resursiv proektno-oriyentovanoyi orhanizatsiyi"], Proceedings of Admiral Makarov NUS, Helvetik Publishing House, No. 1, P. 135-141. DOI: https://doi.org/10.15589/znp2019.1(475).19

Received 12.02.2020

\section{Вiдомості про авторів / Сведения об авторах / About the Authors}

Бондар Алла Віталіївна - кандидат технічних наук, Одеський національний морський університет, доцент кафедри управління логістичними системами i проектами, Одеса, Україна; email: ocheretyankaalla@gmail.com; ORCID: https://orcid.org/0000-0003-2228-2726.

Бондарь Алла Витальевна - кандидат технических наук, Одесский национальный морской университет, доцент кафедры управления логистическими системами и проектами, Одесса, Украина.

Bondar Alla - PhD (Engineering Sciences), Odessa National maritime University, Associate Professor of the Department of Logistic systems and project management, Odessa, Ukraine.

\section{УПРАВЛІННЯ ТРУДОВИМИ РЕСУРСАМИ ПРОСКТНО-ОРІСНТОВАНОӤ ОРГАНІЗАЦІЇ НА БАЗІ ПРОФІЛЮ ФАХІВЦЯ І СТУПЕНЯ ЙОГО УНІКАЛЬНОСТІ}

Предметом дослідження $\epsilon$ інструменти і методи ефективного управління трудовими ресурсами. Метою даного дослідження $\epsilon$ розробка інструментів управління трудовими ресурсами проєктно-орієнтованої організації. У статті вирішуються наступні завдання: введення категорій "профілю фахівця" і "ступеня унікальності" співробітника; ідентифікація основних напрямків використання "профілю фахівця" і показника "ступеня унікальності" в управління трудовими ресурсами проєктноорієнтованої організації; розробка методу оцінки "ступеня унікальності" співробітника. Використовуються такі методи: теорії множин, функціональний аналіз, метод експертних оцінок. Результати. В даному дослідженні введена в розгляд категорія "профіль фахівця" і взаємопов'язаний показник "ступінь унікальності співробітника". Під профілем фахівця розуміється сукупність трьох складових, які представляють собою безлічі кількісно оцінюваних характеристик: компетентності, енергія, професійний потенціал. Профіль фахівця організації розглядається на предмет відповідності не тільки суті проєкту і конкретних його робіт, а й умовам реалізації проєкту і виконання роботи, а також інтересам проєктноорієнтованої організації. "Енергія" - це сукупність особистісних властивостей співробітника, таких як можливість роботи в екстремальних ситуаціях, стресостійкість, комунікабельність і т.п. "Професійний потенціал" - "приховані" професійні можливості (компетентності, енергія), які трансформуються в реальні компетентності і енергію в процесі здійснення професійної діяльності. Розроблено концептуальну модель використання «профілю співробітника» в управлінні трудовими ресурсами проєктно-орієнтованої організації. Під ступенем унікальності співробітника розуміється співвідношення його компетентностей, енергії і потенціалу 3 компетентностями, енергією і потенціалом інших співробітників. Висновки. Розроблено метод оцінки ступеня унікальності співробітника, який проілюстрований розрахунковим прикладом. Позначені напрями використання даного показника в управлінні трудовими ресурсами проєктно-орієнтованої організації.

Ключові слова: трудові ресурси; компетентності; енергія; потенціал; управління; проєкт; ступінь унікальності.

\section{УПРАВЛЕНИЕ ТРУДОВЫМИ РЕСУРСАМИ ПРОЕКТНО-ОРИЕНТИРОВАННОЙ ОРГАНИЗАЦИИ НА БАЗЕ ПРОФИЛЯ СПЕЦИАЛИСТА И СТЕПЕНИ ЕГО УНИКАЛЬНОСТИ}

Предметом исследования являются инструменты и методы эффективного управления трудовыми ресурсами. Целью данного исследования является разработка инструментов управления трудовыми ресурсами проектно-ориентированной 
организации. В статье решаются следующие задачи: введение категорий "профиля специалиста" и "степени уникальности" сотрудника; идентификация основных направлений использования "профиля специалиста" и показателя "степени уникальности" в управления трудовыми ресурсами проектно-ориентированной организации; разработка метода оценки "степени уникальности" сотрудника. Используются следующие методы: теории множеств, функциональный анализ, метод экспертных оценок. Результаты. В данном исследовании введена в рассмотрение категория "профиль специалиста" и взаимосвязанный показатель "степень уникальности сотрудника". Под профилем специалиста понимается совокупность трех составляющих, представляющих собой множества количественно оцениваемых характеристик: компетентности, энергия, профессиональный потенциал. Профиль специалиста организации рассматривается на предмет соответствия не только сущности проекта и конкретных его работ, а и условиям реализации проекта и выполнения работы, а также интересам проектно-ориентированной организации. "Энергия" - это совокупность личностных свойств сотрудника, таких как возможность работы в экстремальных ситуациях, стрессоустойчивость, коммуникабельность и т.п. «Профессиональный потенциал» - "скрытые" профессиональные возможности (компетентности, энергия), которые трансформируются в реальные компетентности и энергию в процессе осуществления профессиональной деятельности. Разработана концептуальная модель использования "профиля сотрудника" в управлении трудовыми ресурсами проектно-ориентированной организации. Под степенью уникальности сотрудника понимается соотношение его компетентностей, энергии и потенциала с компетентностями, энергией и потенциалом других сотрудников. Выводы. Разработан метод оценки степени уникальности сотрудника, который проиллюстрирован расчетным примером. Обозначены направления использования данного показателя в управлении трудовыми ресурсами проектно-ориентированной организации.

Ключевые слова: трудовые ресурсы; компетентности; энергия; потенциал; управление; проект; степень уникальности.

\section{Бібліографічні описи / Bibliographic descriptions}

Бондар А. В. Управління трудовими ресурсами проєктно-орієнтованої організації на базі профілю фахівця і ступеня його унікальності. Сучасний стан наукових досліджень та технологій в промисловості. 2020. № 1 (11). С. $28-34$. DOI: https://doi.org/10.30837/2522-9818.2020.11.028.

Bondar, A. (2020), "Management of human resources of the project-oriented organization based on the profile of the specialist and the degree of its uniqueness", Innovative Technologies and Scientific Solutions for Industries, No. 1 (11), P. $28-34$. DOI: https://doi.org/10.30837/2522-9818.2020.11.028. 